\title{
人工膜および生体膜における透過現象
}

\author{
加茂直樹
}

\author{
北海道大学薬学部 焉 060 札幌市北区北 12 条西 6 丁目
}

小畠陽之助先生の業績を偲ぶという特集に，人工膜お よび生体膜における透過現象という標題で寄稿させてい ただくわけであるが，どのような内容にしようかと少な からず迷ってしまった．この標題での全体的な review を書きはじめると筆者の浅学のために書くことはできな いことが直ちに分かったし，また多岐にわたるための困 難もある. そこで, 小香先生とかつて discussion をし たことを思いだしながら，いくつかの話題について書い てみたい，それは，先生の業績の一部を（ほんの一部に すぎないが）紹介することにもなると思われる．ただ し, 話が古いと感じられる部分があるかも知れないが, その点はお許し願えれば幸いである。

\section{I. 荷電膜の有効荷電密度の概念とその決定法}

1 枚の荷電膜（固定荷電密度は一様とする）が 2 つの 電解質を隔てた系で観測される種々の現象は, flux equation を用いて記述できる.このとき, 2 つ見方がある. 1つは, 膜を 1 つのしきりとみなし, flux equationの 力に水溶液中での化学ポテンシャルの差を初めから導入 するやり方で, discontinuous 系として扱う方法であ る.これは Katchalsky と Curran の有名な教科書 ${ }^{11}$ に記載されている. 他方は, continuous 系として膜を 扱う方法で, 膜内で flux equation を立てる方法であ る. しかし, 観測できる量は, 膜外の水溶液で観測でき る量であるから, flux equation に表れる膜内の物理量 を膜外の量と関連づける必要がある.このため, 膜/水 溶液の界面で, 電気化学ポテンシャルが連続という仮定 を用いるのである ${ }^{2)}$. この仮定は, Donnan 膜平衡が, 膜/水溶液界面のほんの内側と外側で成立するとするも のである. 膜中の固定荷電のために, 移動できるイオン の濃度の不連続が起こり, いわゆる Donnan 電位が発 生する.なお，この不連続を微視的に考察したものに大 島と近藤の仕事 ${ }^{3)}$ がある. また, 膜内濃度と膜外・水溶 液中の濃度の関係も導入する必要がある.

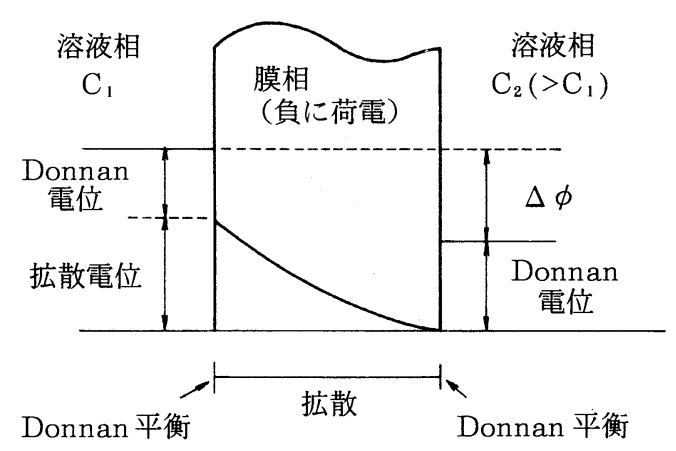

図 1. 考察する系. 同じ $(1: 1)$ 型塩が荷電膜に よって隔てられている

このように, continuous 系としての取り扱いは, 一 見複雑にみえるが，膜を特性づけるパラメータを含むと いう特徵がある.この continuous 系の取り扱いは, 1935 年に Teorell および Mayer と Siever によってなさ れ, TMS の理論として有名である ${ }^{4)}$. TMS 理論は膜電 位を扱っている. その導出は花井の本 ${ }^{5)}$ に詳しい.ここ では，いままであまり紹介されていないが，エレガント な方法 ${ }^{6)}$ で膜電位の基本式を導出してみる.

考える系は図 1 のようである. flux equation として Nernst-Plank の式を採用する. (1: 1) 型塩のみを考 察する. $J_{+}, J_{-}$をそれぞれ陽イオンおよび陰イオンの flux として,

$$
\begin{aligned}
& \mathrm{FJ} J_{+}=-\mathrm{u}_{+} \mathrm{c}_{+} \mathrm{d} \bar{\mu}_{+} / \mathrm{dx} \\
& \mathrm{FJ} J_{-}=-\mathrm{u}_{-} \mathrm{c}_{-} \mathrm{d} \bar{\mu}_{-} / \mathrm{dx}
\end{aligned}
$$

である.ここに, $\mathrm{u}_{i}, \mathrm{c}_{i}, \bar{\mu}_{i}$ はそれぞれ膜内における i イオンの易動度, 濃度, 電気化学ポテンシャルである. Fは Faraday 定数である. (1) 式を $\mathrm{d} \bar{\mu}_{i} / \mathrm{dx}$ に対して 解いて, $\mathrm{x}=0, \mathrm{x}=\mathrm{L}$ での $\bar{\mu}_{i}$ の連続性の仮定のもとに, $\mathrm{x}=0$ から $\mathrm{x}=\mathrm{L}$ まで，その式を積分すれば，

$$
\begin{aligned}
& \Delta \bar{\mu}_{+}=\mathrm{RT} \operatorname{In} \frac{\mathrm{a}_{+}(2)}{\mathrm{a}_{+}(1)}+\mathrm{F} \Delta \phi=-\mathrm{FJ}_{+} \int_{0}^{L} \frac{\mathrm{dx}}{\mathrm{u}_{+} \mathrm{c}_{+}} \\
& \Delta \bar{\mu}_{-}=\mathrm{RT} \operatorname{In} \frac{\mathrm{a}_{-}(2)}{\mathrm{a}_{-}(1)}-\mathrm{F} \Delta \phi=-\mathrm{FJ} J_{-} \int_{0}^{L} \frac{\mathrm{dx}}{\mathrm{u}_{-} \mathrm{c}_{-}}
\end{aligned}
$$


をえる.ここで， J $J_{+}, J_{-}$はxに依存しない，すなわち 定常を仮定している. $a_{i}(j)$ は $\mathrm{i}$ イオンの $\mathrm{j}$ 溶液での活 量である. (2) 式は, continuous な取り扱いから discontinuous な取り扱いへの変換は定常の条件下では容 易であることを意味している（非平衡の熱力学における 線型の flux equation において, 交差項があっても同 様であることは明白である).

膜電位の測定では，電流は流さないので, $J_{+}=J_{-}=J$ であり, $a_{+}=a_{-}=a_{ \pm}$を仮定すれば, (2) 式の辺々差し引 くことにより,

$$
2 \Delta \phi=-\mathrm{J}\left(\int_{0}^{L} \frac{\mathrm{dx}}{\mathrm{u}+\mathrm{c}+}-\int_{0}^{L} \frac{\mathrm{dx}}{\mathrm{u}-\mathrm{c}_{-}}\right)
$$

なる関係式をえる.

一方，(1) 式において， $\bar{\mu}_{i}=\mathrm{RT}$ In $\mathrm{a}_{i}+\mathrm{FZ}{ }_{i} \phi$ の関係 を代入し， $\mathrm{J}_{+}=\mathrm{J}_{-}$であることを利用して $\mathrm{d} \phi / \mathrm{dx}$ の項 を消去すると，

$$
\mathrm{J}=\mathrm{J}_{+}=\mathrm{J}_{-}=2 \frac{\mathrm{RT}}{\mathrm{F}} \frac{\mathrm{u}+\mathrm{c}_{+}-\mathrm{u}_{-} \mathrm{c}_{-}}{\mathrm{u}_{+} \mathrm{c}_{+}+\mathrm{d}_{-} \mathrm{c}_{-}} \frac{\mathrm{In} \mathrm{a}_{ \pm}}{\mathrm{dx}}
$$

をえる.（4）式に代入すると，次式をえる，

$$
\Delta \phi=-\frac{\mathrm{RT}}{\mathrm{F}} \int_{0}^{L} \frac{\mathrm{u}_{+} \mathrm{c}_{+} \mathrm{u}_{-} \mathrm{c}_{-}}{\mathrm{u}_{+} \mathrm{c}_{+}+\mathrm{u}_{-} \mathrm{c}_{-}} \mathrm{d} \operatorname{In} \mathrm{a}_{ \pm}
$$

この式が図 1 に述べた系に対する膜電位 $\Delta \phi$ の式であ る.

さて, TMS の理論は, (i) 膜中のイオンの活量係数 はすべて 1 である.（ii）膜中での易動度の比, $u_{+} / u_{-}$ は一定である.（iii）膜の固定荷電濃度 $\times$ は塩濃度によ らず一定でかっ一様である．膜は負に荷電している場合 を考えることにすると， $\mathrm{C}_{+}=\mathrm{C}_{-}+\mathrm{X}$ である．亡の仮定 をしている.

これらの仮定のもとに (5) 式は容易に積分できて,

$$
\begin{aligned}
\Delta \phi= & -\frac{\mathrm{RT}}{\mathrm{F}}\left[\operatorname{In} \frac{\xi_{2}}{\xi_{1}}+\overline{\mathrm{U}} \operatorname{In} \frac{\left(1+\varphi \xi_{2}^{2}\right)^{1 / 2}+\overline{\mathrm{U}}}{\left(1+\varphi \xi_{1}^{2}\right)^{1 / 2}+\overline{\mathrm{U}}}\right. \\
& \left.-\operatorname{In} \frac{\left(1+\varphi \xi_{2}^{2}\right)^{1 / 2}+1}{\left(1+\varphi \xi_{1}^{2}\right)^{1 / 2}+1}\right] \quad(6)
\end{aligned}
$$

となる ${ }^{2)}$.ここで， $\xi$ $\mathrm{C} / \mathrm{X}$ で定義された還元濃度, $\overline{\mathrm{U}}$ は $\left(\mathrm{u}_{+}-\mathrm{u}_{-}\right) /\left(\mathrm{u}_{+}+\mathrm{u}_{-}\right)$であり, 一定之仮定する.

この式は弌とXをパラメータとする. U一は次のように して推定できる. まず見掛けの陰イオンの輸率 $\tau_{-a p p}$ を $\Delta \varphi=-(\mathrm{RT} / \mathrm{F}) \times\left(1-2 \tau_{a p p}^{-}\right)$In $\left(\mathrm{C}_{2} / \mathrm{C}_{1}\right)$

で定義して, (6) 式と等置し濃度比 $\beta\left(\equiv \mathrm{C}_{2} / \mathrm{C}_{1}\right)$ を一
定に保って塩濃度の高い所, $\xi_{1}=\mathrm{C}_{1} / \mathrm{X}(\gg 1)$ で展開し てみる. 得られた展開式は $1 / \tau_{a p p}^{-}$を $1 / \xi_{1}\left(=\mathrm{X} / \mathrm{C}_{1}\right)$ に対してプロットすれば，その $\mathrm{y}$ 軸切片から $\bar{U} の$ 值の求 まることを示す.このようにして求めたŪの值は, 電解 質溶液中における値と等しかった ${ }^{2)}$.

一方，Xは分析によって決定することができる，した がって，(6) 式はすべてのパラメータが既知であるので 計算することができ, 実駼值と比較することができる. 比較の結果は定性的にはよいが，定量的には全く一致し ない2)。一致しない実例は文献2)を参照されたい。この 不一致の原因は小畠らによって研究され,「有効荷電密 度」の概念が提出された ${ }^{7)}$. 阪大理時代の先生の有名な 仕事の一つである. 他に, この時代では異常浸透の研 究 ${ }^{8)}$ がある.

有効荷電密度の概念は, 高分子電解質溶液中の活量に ついて提出されていた概念である。 それは，TMS 理論 の仮定 (i) や (ii) の正しさの検証である. 高分子電解 質溶液の研究において, 添加塩の活量係数（および高分 子電解質溶液の浸透圧係数)に対して “additivity rule” と呼ばれている簡単な経験則 ${ }^{9)}$ がある.この ruleによ ると，高分子はマイナスの荷電をおびているとして，対 イオンである陽イオンの活量係数を $\gamma_{+1}$, 副イオンであ る陰イオンのそれを $\gamma_{-}$と書けば, これらは

$$
\gamma_{+}=\gamma_{+}{ }^{0}\left(\mathrm{C}_{-}\right) \frac{\mathrm{C}_{-}+\phi \mathrm{X}}{\mathrm{C}_{-}+\mathrm{X}}, \gamma=\gamma_{-}^{0}\left(\mathrm{C}_{-}\right)
$$

と書ける. $\phi$ は $0<\phi<1$ のパラメータである.ここで, $\gamma_{+}{ }^{0}\left(\mathrm{C}_{-}\right), \gamma_{-}{ }^{0}\left(\mathrm{C}_{-}\right)$に高分子 free の溶液における活 量係数である. 陰イオンは高分子鎖上の固定電荷との電 気的反発により，鎖から十分遠い之ころに主に存在する ので, 高分子を含まない溶液における值と等しいと考え る. 反対に陰イオンは, 高分子鎖上の密に存在する固定 電荷の作る大きな静電ポテンシャルのために, 活量係数 が低下するのである．1つのイメージは，対イオンが大 きな静電ポテンシャルによって「固定」され, 固定荷電 密度がXから $\phi \mathrm{X}$ に低下する.

易動度に関する仮定として, 小畠らは，(8) 式と類似 の

$$
\mathrm{u}_{+}=\mathrm{u}_{+}{ }^{0} \frac{\mathrm{C}_{-}+\phi^{\prime} \mathrm{X}}{\mathrm{C}_{-}+\mathrm{X}}, \mathrm{u}_{-}=\mathrm{u}_{-}{ }^{0}
$$

を仮定した ${ }^{0)}$ 。易動度に対しては, 「有効荷電」は $\phi^{\prime} \mathrm{X}$ であるとした.

実験的研究によって, 得られた結論は, $\phi=\phi^{\prime}$ とお いてもさしつかえないこと, また $\phi$ 值は濃度依存性を 
示した ${ }^{0)}$. ただし，全体的にみると $\phi$ 一定としても 満足できるものであった. (8), (9) 式を用いて, (5) 式 を積分してみると，(6) 式と全く同じ式をえる，ただし，

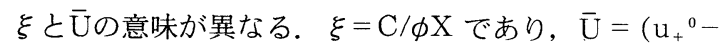
$\left.\mathrm{u}_{-}{ }^{0}\right) /\left(\mathrm{u}_{+}{ }^{0}+\mathrm{u}_{-}{ }^{0}\right)$ である. U一意味は TMS のもともと のものと大きく異ならないが, $\xi$ の意味は大きく異なる. すなわち, 有効荷電密度が膜現象を決定する. $\Delta \phi$ のみ ならず，膜抵抗も $\phi \mathrm{X}$ に決まるからである.

次の問題は $\phi \mathrm{X}$ の決定法である. 膜電位測定は簡便で あるので $\Delta \phi$ から $\phi \mathrm{X}$ の推定法を案出した ${ }^{7)}$. まず考察 すべきことは, (7) 式の $\tau_{a p p}^{-}$の意味である.いま, $\Delta \phi$ の式において, 膜の両側の水溶液の濃度比 $\beta$ を 1 に近づ けると

$$
\Delta \phi=-\frac{\mathrm{RT}}{\mathrm{F}}\left(\frac{\mathrm{u}+\mathrm{c}_{+}-\mathrm{u}_{-} \mathrm{c}_{-}}{\mathrm{u}_{+} \mathrm{c}_{+}+\mathrm{u}_{-} \mathrm{c}_{-}}\right) \operatorname{In} \beta+\cdots \cdots
$$

の形になる.ここで液間電位の取り扱いを参考にして

$$
\tau^{-}=\frac{\mathrm{u}_{-} \mathrm{c}_{-}}{\mathrm{u}+\mathrm{c}_{+}+\mathrm{u}_{+} \mathrm{c}_{-}}
$$

とおくことができる，そして， $\tau^{-}$は濃度差のない条件 で定義された輸率である。ただし, 電解質溶液と異なり 荷電膜の場合は, 濃度差なしの条件で電流を流し, 陰イ オンが運ぶ全電流に対する割合は $\tau^{-}$ではない，それは 重心の移動（水の移動）があるからである ${ }^{11)}$. $\tau_{a p p}^{-}$と $\tau^{-}$との関係を考察する．すなわち， $\tau_{a p p}^{-}$は膜に濃度勾 配が存在するときの陰イオンの輸率であり， $\tau^{-}$は濃度 勾配のないときの重心に相対的な陰イオンの輸率であ り，(8)，(9) 式の仮定とDonnan 平衡を用いれば, $\overline{\mathrm{U}}=$ $\left(\mathrm{u}_{+}{ }^{0}-\mathrm{u}_{-}{ }^{0}\right) /\left(\mathrm{u}_{+}{ }^{0}+\mathrm{u}_{+}{ }^{0}\right)$ よ $\phi \mathrm{X}\left(=\phi^{\prime} \mathrm{X}\right)$ を含む式として 求まる。 U一既知であるから， $\phi \mathrm{X}$ が求まることになる. 一方, 実験的には $\tau_{a p p}^{-}$が求まる. そこで, 以前は $\tau_{a p p}^{-}$ は $\left(\mathrm{C}_{1}+\mathrm{C}_{2}\right) / 2$ の濃度における $\tau^{-}$に等しいと仮定して, 議論を進め, 膜電位の測定 $\rightarrow \tau_{a p p}^{-}$の決定 $\rightarrow\left(\mathrm{C}_{1}+\mathrm{C}_{2}\right) /$ 2 における $\tau^{-}$とする $\rightarrow \mathrm{X}$ の決定という手順で荷電膜 の有効荷電密度を推定できるという論文 ${ }^{7}$ を発表した。 そして, この方法は, 生体膜にも適用できる簡便な方法 であるとされてきた.

しかし， $\tau_{a p p}^{-}$を $\left(\mathrm{C}_{1}+\mathrm{C}_{2}\right) / 2$ における $\tau^{-}$とする（文 献 12 を見ていただくと $\beta$ 小さい範囲で成立すること が示されている）という考えは，膜内で塩の分布が直線 的であるということを暗に想定している.これについて， 以前に小畠先生と検討をしてみたことがある. 図 2-A に計算結果を示す。この図から分かるように， $\beta$ が小 い範囲では確かに $\tau_{a p p}^{-}=\tau^{-}$としてよい. しかし， $\beta$ が
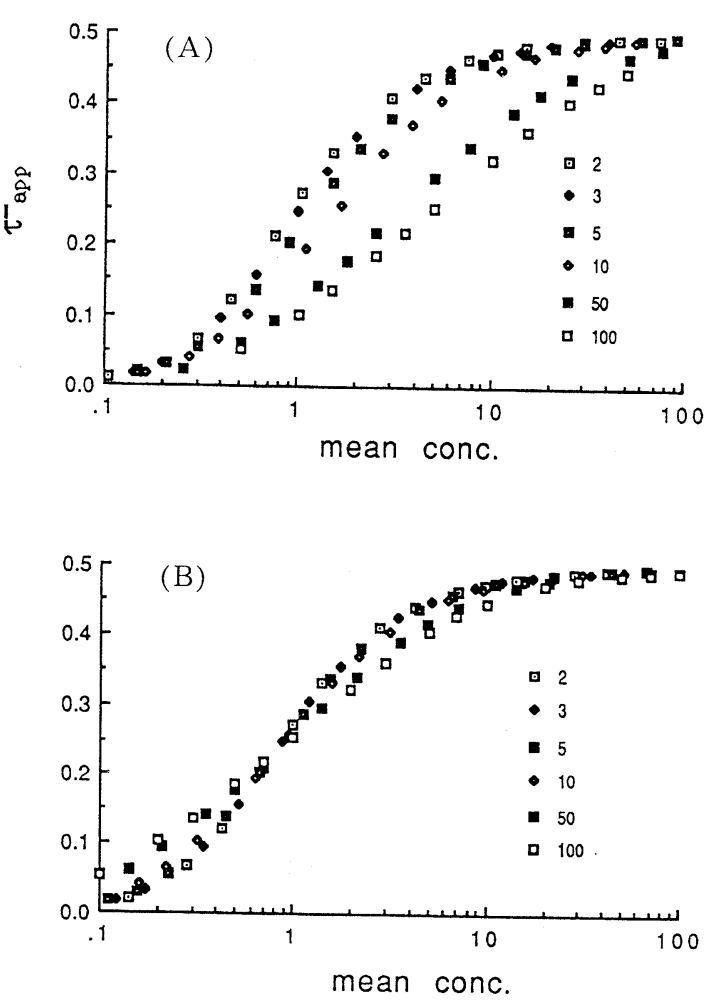

図 2. $\tau_{a p p}^{-}$vs mean concentration. (A)は mean concentration として, $\left(\mathrm{C}_{1}+\mathrm{C}_{2}\right) / 2$ を, (B) は $\sqrt{\mathrm{C}_{1} \mathrm{C}_{2}}$ 亡した. 図中の数字は $\mathrm{C}_{2} / \mathrm{C}_{1}$ の 值である。

10，50，100のような值になると，明らかに大きくずれ てくる．この意味で以前の論文には欠陥がある.

今回, 本小論を書くにあたって, $\left(\mathrm{C}_{1}+\mathrm{C}_{2}\right) / 2$ の代わ りに相乗平均, $\sqrt{\mathrm{C}_{1} \mathrm{C}_{2}}$ を使用してみたらどうかと思い つき, 計算してみた結果が図 2-Bである. 図 2-A に比 ベて, より $\beta$ 依存性がない曲線となっていることが分 かる.したがって, $\sqrt{\mathrm{C}_{1} \mathrm{C}_{2}}$ を使用した方がよい. ただ し, この理論的裏付けはない，膜内の濃度分布を計算し てみたいと思っている。

\section{II. 第 2 次能動輸送における熱力学的考察よ kinetic approach}

生体膜を介する能動輸送には, 第 1 次, 第 2 次能動輸 送がある. 非平衡の熱力学の立場から, 物質 $\mathrm{i}$ の輸送速 度は 3 つの項からなる.すなわち,

( $\mathrm{i}$ の輸送速度 $)=(\mathrm{i}$ 自身の拡散 $)+($ 他の物質の移動 との共役 $)+($ 化学反応に基づく $)$ 
第 2 項に基づく輸送が第 2 次能動輸送であり，第 3 項に 基づくものが第 1 次能動輸送と呼ばれている ${ }^{13)}$.

第 1 次能動輸送には, 呼吸鎖による $\mathrm{H}^{+}$の排出, 光リ ン酸化の際の $\mathrm{H}^{+}$の排出, バクテリオロドプシンやハロ ロドプシンによる光駆動イオンポンプ, イオン輸送性 ATPase (Na, K-ATPase, Ca-ATPase, H-ATPase, $\mathrm{K}, \mathrm{H}-\mathrm{ATP}$ ase等）がある. 第 2 次能動輸送は第 1 次能 動輸送で作られたイオン（Aとする）の勾配によって, Aが電気化学ポテンシャルにしたがって透過するのに共 役して, 他の物質 $\mathrm{S}$ が(電気) 化学ポテンシャルに逆らっ て輸送される現象である. A と S 移動方向によって 2 つに分類されている．AとSが同じ方向の場合は等方輸 送 (symport) または共輸送 (co-transport) と呼ばれ ている. Aと Sが逆方向の場合は対向輸送 (anti-port) と呼ばれる. その他に単独輸送 (uniport) と呼ばれる 場合がある.これは第 1 次能動輸送で作られた膜電位に よってイオンが電気泳動的に移動し，濃縮される場合で ある。

uniport を除いて, 第 1 次能動輸送, シンポート，ア ンチポートのいずれにしても, 輸送タンパクが関与し, タンパク質の構造変化と共役して輸送が起こる. 1 つの タンパクが単位時間に多数の物質を輸送するためには, その構造変化は循環的である必要がある. したがって, $\mathrm{Na}, \mathrm{K}$-ATPase, Ca-ATPase の cyclic model が提案 されてきた.また，第 2 次能動輸送でも cyclic model で説明される.これらのタンパクの一次構造が次々と明 らかになってきているので, 近い将来, 輸送の分子機構 が明らかになると思われる。

バクテリオロドプシン $(\mathrm{bR})$ とハロロドプシン $(\mathrm{hR})$

は, 高度好塩菌の細胞膜に存在する光で駆動されるイオ ンポンプである ${ }^{14)}$. すなわち, 光照射によって, $b R$ は $\mathrm{H}^{+}$を細胞内から外へ輸送して, 細胞内負の膜電位 と外の酸性を生じ, ATP 合成の駆動力となる，hR は 光クロライドポンプであり, 光照射によって $\mathrm{Cl}$ が細 胞外から内一輸送され, 細胞内負の膜電位が形成され る.これらはレチナール (ビタミンAのアルデヒド型) を発色団として持っており, 光照射によってレチナー ルが all-trans 型から 13-cis 型に変化し, タンパクの 構造変化が起こる. この構造変化によって $\mathrm{H}^{+} や \mathrm{Cl}^{-}$ が一方方向にタンパク内を移動する. bR では $\mathrm{H}^{+}$- ポ ンプであるので, アミノ酸残基の解離, 非解離によっ て $\mathrm{H}^{+}$が輸送され, この輸送に関与するアミノ酸残基 も同定されている(5). $b R や h R$ の光化学はサイクリックである.つまり, 光照射によって分子は励起され種々の光化学中間体を経 て，もとの bRやhRにもどる.これをホトサイクルと 呼んでいる. $\mathrm{bR}$ では $\mathrm{pH}$ 色素を用いて，ホトサイクル のよ゙こで $\mathrm{H}^{+}$が遊離されまた再結合するか決定されてい $3^{14)}$. hR の場合は $\mathrm{Cl}^{-}$の存在下(少なくとも数 $10 \mathrm{mM}$ ) で $\mathrm{Cl}^{-}$のタンパクへの出入を測定しなければならないた め, 直接の $\mathrm{Cl}^{-}$の遊離, 再結合の測定はいまだなされて いないが, $h R$ の種々の溶液中での分光学的な性質から, $\mathrm{C} \Gamma$ の遊離亡再結合型 $\mathrm{hR}$ がそのホトサイクル上に表れる と考えられている．他の輸送担体でも，たとえば $\mathrm{Na}$ ， K-ATPase では Naの結合，酵素のリン酸化， $\mathrm{Na}$ の 脱離, $\mathrm{K}$ の結合, 脱リン酸化, $\mathrm{K}$ の脱離のサイクルが繰り 返されている。これらの例において，1つのステップで 1 つのみの仕事をしている。たとえば, bRにおいて $\mathrm{H}^{+}$の 放出と吸収が同時に起こることはない. hR において $\mathrm{Cl}^{-}$ の放出と吸収は同時に起こらない. Na, K-ATPase で は, 膜内側の $\mathrm{Na}^{+}$結合部位と膜外側の $\mathrm{K}^{+}$結合部位が 同時に存在するようなデータもあるというが，このとき は，半位相だけずれた 2 つサブユニットから 1 分子の ATPase となると考え, 1 つのサブユニットでは, 1 ス テップに 1 つ仕事と考えている ${ }^{16)}$.

次に機構について考察する. 膜のうち側と外側でキャ リアプロテインに対する親和力が異なると考える．うち 側では親和力が弱くて, 外側では強いと考えると, 基質 は外から内へと輸送される．この親和力の相違によって 濃度勾配に逆らって輸送されると考えるのである.すな わち, 両水溶液間でみれば濃度差に逆らっているのだ が，膜内では濃度勾配に従っているのである. キャリ アーの親和力の非対称性は，膜系に加えられたエネル ギーに由来すると考える. 第 1 次能動輸送では化学反応 や光のエネルギーがキャリアーの非対称性を作り, 第 2 次能動輸送では，基質輸送を駆動する他のイオンの存在 によって非対称性が作られる. 人工膜で濃度勾配に逆 らった輸送を行わせる研究が多数なされているが, これ らはこの原理を用いている. なお小畠先生のグループで は,かなりの初期に『能動輸送人工膜』を発表してい $3^{17)}$.

図 3 に高度好塩菌におけるエネルギー変換のスキーム を示した. 高度好塩菌はその名の通り, きわめて高濃度 の $\mathrm{NaCl}(4.3 \mathrm{M})$ 中で培養されるバクテリアで, 自然 界では塩田のあとの潮だまりや, 死海, The Great Salt Lakeなどに生息している. 


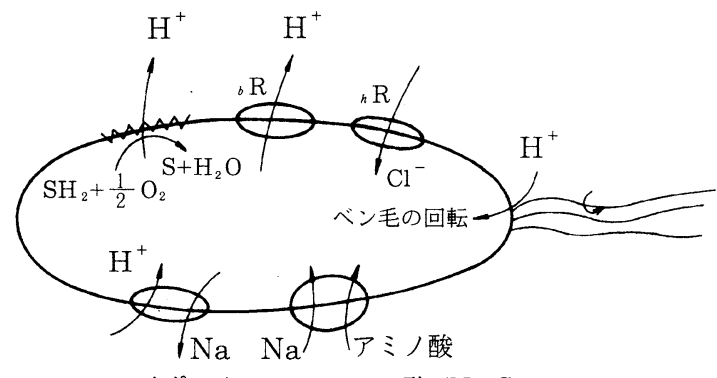

$\mathrm{Na} / \mathrm{H}$ アンチポーターアミノ酸/ $\mathrm{Na}$ Symporter

図 3. 高度好塩菌のエネルギ一変換

バクテリオロドプシンや呼吸によって, $\mathrm{H}^{+}$が細胞外 へ排出される.これによって生じた $\mathrm{H}^{+}$の電気化学ポテ ンシャルは ATP 合成と Na の排出を駆動する. ベン毛 の回転もこれを駆動力としている. $\mathrm{Na}$ の排出は $\mathrm{Na} / \mathrm{H}$ アンチポータによってなされる. 高度好塩菌の $\mathrm{Na} / \mathrm{H}$ アンチポータは，いき值現象といわれる興味ある現象が 見いだされている．すなわち，細胞内負の膜電位が 120 $\mathrm{mV}$ 程度以上よりも大きくならないよ, $\mathrm{Na} / \mathrm{H}$ アンチ ポータは働かない.チャンネルと輸送担体との違いはあ るが，神経の Na-チャネルの開閉を連想させられて， 興味深い. この $\mathrm{Na} / \mathrm{H}$ アンチポータによって, 外界が 飽和に近い $\mathrm{Na}$ 濃度であるのに, 細胞内の $\mathrm{Na}$ 濃度は低 く，おそらく $100 \mathrm{mM}$ 以下に保たれている（次に述べ ることからは, 細胞内 $\mathrm{Na}$ 濃度はもっと低くなければな らないと推定されるけれども)。この $\mathrm{Na}$ 濃度勾配が駆 動力となって,アミノ酸が取り込まれる.

アミノ酸の一種であるグルタミン酸の高度好塩菌膜べ ジクルの取り込みの駆動力は, $\mathrm{Na}$ の濃度勾配のみであ り, 膜電位は関与しない. グルタミン酸とキャリアータ ンパクとの複合体が，中性であるからであると推定され ている．膜電位が関与しないことは，ベジクル内外を $3 \mathrm{M} \mathrm{NaCl}$ の条件にして, 光照射して bRによって膜 電位を発生させても, グルタミン酸の取り込みはみら れない. しかし, 図 4 に示すように, 小胞内 $3 \mathrm{M} \mathrm{KCl}$, 外 $3 \mathrm{M} \mathrm{NaCl}$ の $\mathrm{Na}$ 濃度勾配をつけると，暗所でもグ ルタミン酸の取り込みが観察される. 駆動力は $\mathrm{Na}$ の 電気化学ポテンシャルの活量項のみの差 $\Delta \mu \mathrm{Na}=\mathrm{RT}$ In $[\mathrm{Na}]$ in/[Na] outである.したがって, 非平衡の熱 力学によれば, グルタミン酸の流束は $\Delta \mu \mathrm{Na}$ に比例す るはずである.

このような輸送現象の kinetic な解析として, 図 5 の ような cyclic なモデルが用いられる. 1 ステップに $1 つ$

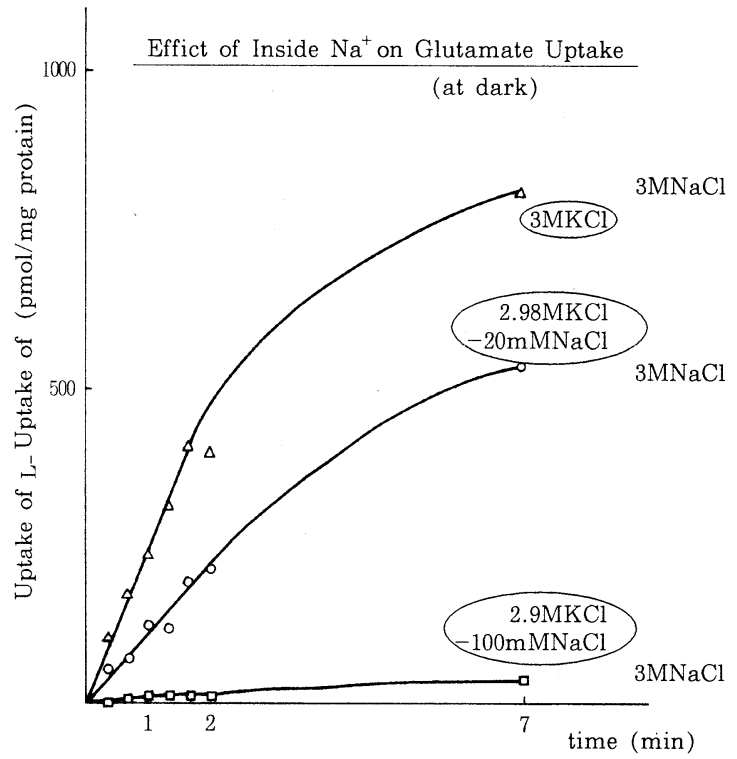

図 4. 高度好塩菌膜ベジクルにおけるグルタミン 酸のとり込み（石飛明子，未発表データ）

の仕事をすると考えられ, $\mathrm{Na}$ とグルタミン酸 $(\mathrm{M})$ の キャリアー $(\mathrm{C})$ への結合, 解離の過程を含む.このと き， Cに Na が先に結合するか，Mが先に結合するかの 2 通りがある. また, 膜の内側でのグルタミン酸 $\left(\mathrm{M}^{\prime}\right.$ 之記す）の複合体の解離においても， $\mathrm{M}^{\prime}$ が先に解離す るか $\mathrm{Na}^{\prime}$ が先に解離するかの 2 通りがある. しかし, ほとんよ゙といっても過言でないほよ゙, NaがCに結合 し，続いてMが結合する順序であれば，内側では，まず Mが解離し, 続いて $\mathrm{Na}$ が解離するか, その逆に $\mathrm{M}, \mathrm{Na}$ と結合すれば， $\mathrm{Na}, \mathrm{M}$ と解離するとの 2 つの場合のみ を考える．この理由は筆者には不明である，図のように 混合型 (random binding) を考える場合もある. random binding の考え方をとるよりも, co-substrate で ある Naと substrateであるMが同時か, 順にか (ordered) のいずれかの方が妥当に筆者には思える. bR の例 から考えれば, ordered を考えたくなる。

図 4 は高度好塩菌膜ベジクルを用いたグルタミン酸の 取り込みに対する小胞内 $\mathrm{Na}$ 濃度の効果を調べたもので ある. 小胞外は $3 \mathrm{M} \mathrm{NaCl}$ に保っている．小胞内に 100 $\mathrm{mM}$ の $\mathrm{Na}$ を負荷した小胞では, 図に示す通り，ほ之 んど取り込みが見られない。これから次の 3 点を議論し たい.

まず最初に, 生菌の細胞内 $\mathrm{Na}$ 濃度は $100 \mathrm{mM}$ 以下 でなければ，グルタミン酸の取り込みは起こらないこと 
model 1

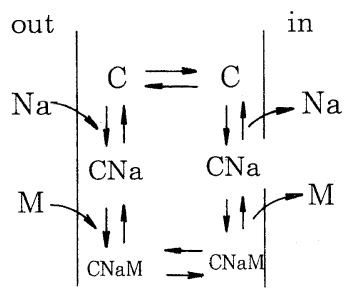

model 2

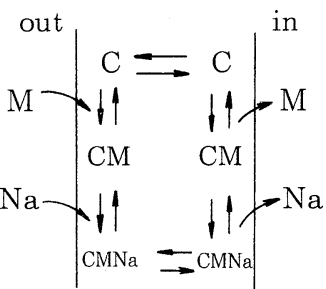

model 3

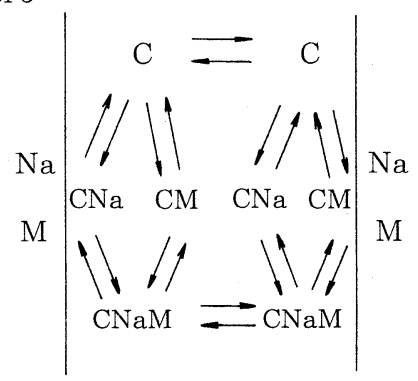

図 5. Symportの Kinetic model

になる. 細胞外液は $4.3 \mathrm{M} \mathrm{NaCl}$ であるから, 細胞内 $\mathrm{Na}$ 濃度が $100 \mathrm{mM}$ 以下であることは, $\mathrm{Na} / \mathrm{H}$ アンチポー タが強力であることか膜小胞を作るときに何かの因子が 欠損したためのどちらかであろうと考えられる.

第 2 点は, kinetic なモデルをMの結合 $\rightarrow \mathrm{Na}$ の結合 $\rightarrow \mathrm{CMNa}$ の複合体の translocate $\rightarrow \mathrm{Na}$ の解離 $\rightarrow \mathrm{M}$ の 解離 $\rightarrow$ 空のCの translocate という ordered で考えれ ば，小胞内 $\mathrm{M}$ の濃度 $=0$ の条件（初速のみに注目する） で流入速度を計算すると, 小胞内の $\mathrm{Na}$ 濃度に速度は依 存しないという結果がえられる. したがって，このモデ ルではなく, 多分, $\mathrm{Na}, \mathrm{M}$ と結合し, $\mathrm{M}, \mathrm{Na}$ と解離す るモデルが妥当と思われる.

最後の疑問は，このような kinetic な取り扱いと熱力 学的取り扱いとの関係である. 熱力学的には, $\Delta \mu \mathrm{Na}$ 駆動力であるので, 取り込み速度も $\Delta \mu \mathrm{Na}$ が関与する と思われる. 事実, 図 4 に示したように小胞に少量の $\mathrm{Na}$ の存在で大きく初速が減少するのは, log [Na] out/[Na] in の大きな減少と考えれば考えやすいのであ るが, kinetic な取り扱いでは, 小胞内 $\mathrm{Na}$ 濃度に依存 しないような kinetics もえられる. 化学反応の速度と 熱力学的取り扱いが全く関連がないことと同様であると は思うが，不思議に思っている点である。

以上, 科学的総説というよりかは, 思いつきのみを書
いたものに近く，恐縮である. 小畠先生と討論したこと のある点について書かせて頂いた。

\section{文献}

1） A. カチャルスキー, P.F. カラン（青野, 木原, 大 野共訳）生物物理学における非平衡の熱力学, みす ず書房 (1975)

2) Y. Kobatake, Y. Toyoshima, N. Takeguchi, J. Phys. Chem. 70, 1187 (1966), 加茂直樹, 小畠陽 之助, 生物物理 11, 23 (1971), Y. Kobatake, N. Kamo, Prog. poly. Sci. Japan 5, 257 (1973)

3) H. Ohshima, S. Ohki, Biophys. J., 47, 673 (1985)

4) T. Teorell, proc. Soc. Exptl. Biol., 33, 282 (1935) ; K.H. Meyer, J.F. Sievers, Helv. Chim. Acta 19, 649, 665, 987 (1936)

5) 花井哲也, 膜とイオン, 化学同人, 京都 (1978)

6) Y. Kobatake, Y. Toyoshima, N. Takeguchi, J. Phys. Chem. 70, 1187 (1966)

7) N. Kamo, M. Oikawa, Y. Kobatake, J. Phys. Chem., 77, 92 (1973)

8) Y. Toyoshima, Y. Kobatake, H. Fujita, Trans. Faraday Soc., 63, 2828 (1967) ; 小畠陽之助, 高 分子 17, 768 (1968)

9) S. Rice, M. Nagasawa, "Polyelectrolyte Solution" Academic Press, New York, (1961) ; A. Katchalsky, Z . Alexandrowicz, O. Kedem, "Chemical Physics of Ionic Solutions (ed. B. 
E. Conway and R.G. Barradas) John Wiley and Sons. Inc., New York, 296 (1966) ; G.S. Manning, J. Chem. Phys., 51, 924 (1969)

10) Y. Toyoshima, M. Yuasa, Y. Kobatake, H. Fujita, Trans. Faraday. Soc., 63, 2803 (1967)

11) N. Kamo, Y. Kobatake, Kolloid-z.u,z. Polymere 249, 1069 (1971)

12) N. Kamo, Y. Toyoshima, Y. Kobatake, Kolloid-z.u.z. Polymere 249, 1061 (1971)

13）小畠陽之助, 生体現象の物理化学, 講談社サイエン ティフィク (1987)

14) W. Stoeckenius, R.A. Bogomolni, Ann. Rev. Biochem., 52, 587 (1981) ; J. K. Lanyi, Ann.
Rev. Biophys. Chem., 15, 11 (1986)

15) T. Mogi, L.J. Stern, T. Marti, B.H. Chao, H. G. Khorana, Proc. Natl. Acad. Sic. USA, 85, 4148 (1988) ; H.J. Butt, K. Fendler, E. Bamberg, J. Tittor, D. Oesterhelt, EMBO J. 8, 1657 (1989)

16）殿村雄治, 佐藤 了, 生体膜の構造と機能, 講談社 サイエンティフィク (1979)

17）総説として, Y. Kobatake, N. Kamo, T. Shinbo in "Membranes and Membane Processes" E. Drioli and M. Nakagaki ed. Plenum Publishing Corporation (1986)

（受付 1989.11.6.) 